\title{
The Talmud, the Hippocratic Corpus and Mark's healing Jesus on infectious diseases
}

\begin{tabular}{|c|c|}
\hline $\begin{array}{l}\text { Author: } \\
\text { Zorodzai Dube }\end{array}$ & 1 (1) \\
\hline $\begin{array}{l}\text { Affiliation: } \\
\text { 'Department } \\
\text { Testament Stu } \\
\text { of Theology a } \\
\text { University of } \\
\text { South Africa }\end{array}$ & $\begin{array}{l}\text { f New } \\
\text { dies, Faculty } \\
\text { d Religion, } \\
\text { retoria, }\end{array}$ \\
\hline $\begin{array}{l}\text { Research Proj } \\
\text { Project Leade } \\
\text { Project Numb }\end{array}$ & $\begin{array}{l}\text { ect Details: } \\
\text { r: Z. Dube } \\
\text { er: } 13339746\end{array}$ \\
\hline $\begin{array}{l}\text { Description: } \\
\text { This research } \\
\text { project, 'Heali } \\
\text { New Testame } \\
\text { Dr Dube, Dep } \\
\text { Testament Stu } \\
\text { of Theology a } \\
\text { University of F } \\
\text { South Africa. }\end{array}$ & $\begin{array}{l}\text { s part of the } \\
\text { ng during the } \\
t^{\prime} \text { ', directed by } \\
\text { artment of New } \\
\text { dies, Faculty } \\
\text { 'd Religion, } \\
\text { retoria, }\end{array}$ \\
\hline $\begin{array}{l}\text { Correspondin } \\
\text { Zoro Dube, } \\
\text { zoro.dube@u }\end{array}$ & $\begin{array}{l}\text { g author: } \\
\text { o.ac.za }\end{array}$ \\
\hline $\begin{array}{l}\text { Dates: } \\
\text { Received: } 24 \text { I } \\
\text { Accepted: } 15 \\
\text { Published: } 30\end{array}$ & $\begin{array}{l}\text { Mar. } 2018 \\
\text { une } 2018 \\
\text { July } 2018\end{array}$ \\
\hline $\begin{array}{l}\text { How to cite th } \\
\text { Dube, Z., } 2018 \\
\text { the Hippocrat } \\
\text { Mark's healin } \\
\text { infectious dise } \\
\text { Teologiese Stu } \\
\text { Theological St } \\
\text { 4985. https:// } \\
\text { 10.4102/hts.V }\end{array}$ & $\begin{array}{l}\text { is article: } \\
\text {, 'The Talmud, } \\
\text { c Corpus and } \\
\text { Jesus on } \\
\text { ases', HTS } \\
\text { dies/ } \\
\text { udies 74(1), } \\
\text { doi.org/ } \\
74 \text { i1.4985 }\end{array}$ \\
\hline $\begin{array}{l}\text { Copyright: } \\
\text { ( 2018. The } \\
\text { Licensee: AOS } \\
\text { is licensed un } \\
\text { Creative Comr } \\
\text { Attribution Lic }\end{array}$ & $\begin{array}{l}\text { luthors. } \\
\text { IS. This work } \\
\text { ler the } \\
\text { nons } \\
\text { ense. }\end{array}$ \\
\hline Read online: & \\
\hline 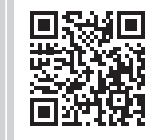 & $\begin{array}{l}\text { Scan this QR } \\
\text { code with your } \\
\text { smart phone or } \\
\text { mobile device } \\
\text { to read online. }\end{array}$ \\
\hline
\end{tabular}

\section{Author:}

Affiliation

${ }^{1}$ Department of New of Theology and Religion, University of Pretoria

Project Leader: Z. Dube

Description:

This research is part of the Dr Dube, Department of New Testament Studies, Faculty University of Pretoria, South Africa.

Corresponding author: Zoro Dube,

Dates:

Received: 24 Mar. 2018 Accepted: 15 June 2018

How to cite this article: Mark's healing Jesus on infectious diseases', HTS 4985. https://doi.org/ Copyright: (C) 2018. The Authors is licensed under the Creative Commons Attribution License. mobile device to read online.
Through interacting with the sick, did Jesus contract infectious diseases or did he take preventive herbs to avoid them? During biblical times, infectious diseases were fatal. Diarrhoea, cough, pneumonia and skin diseases would quickly spread across villages or cities. Underscoring the seriousness with which prevention of infectious diseases was taken, 213 of the 613 biblical commandments concern hygiene. This study has two tasks: firstly, exploring the various techniques undertaken to avoid infectious diseases by looking at daily preventive hygienic activities. Secondly, given that Jesus was always in the company of sick crowds, the study re-describes Mark 1:4-45, where Jesus, after healing the leper, was forbidden from entering the city as indicative of fear against infectious diseases. Furthermore, the story (Mk 3:7-12) whereby Jesus requested a boat to create a gap between himself and the people is plausible from the perspective of infectious diseases.

\section{Introduction}

In recent years the study of Jesus has focused on his context, that is, how he challenged cultural and political issues that oppressed people through his initiation of the imaginary kingdom of God (Moxnes 2003). Two discursive perspectives inform this reconstruction of Jesus: firstly, the influence of liberation paradigms, which makes it possible to imagine Jesus as a liberator who questions imperial dominance. This is exemplified by New Testament scholars such as Ched Myers and Richard Horsley (Horsley 2001; Myers 1988). From this tributary, Jesus' healing stories are a paradigm for social activism, helping sick people through healing and feeding them within the household (Malbon 1986; Van Eck 1993). The second perspective, from a social scientific approach, influenced by feministic approaches, questions household structures and gender relations (Fiorenza 1979; Moxnes 2003).

While still continuing with the perspective of the context of Jesus, I seek to bring the social variable of infectious diseases to the discussion of Jesus as healer. Unlike the approach taken by Ernest van Eck and Elizabeth Malbon, who view the healings in the house as a sign of commensality, love and hospitality, I am interested in Jesus as the vulnerable healer. My hypothesis is that, given that Mark's gospel is among the earliest tradition, he provides the earliest memories of Jesus as a vulnerable healer. In the earliest chapters, after healing Simon's mother-in-law, Mark reports, saying:

That evening at sundown they brought to him all who were sick or oppressed by demons. And the whole city was gathered together at the door. And he healed many who were sick with various diseases, and cast out many demons. And he would not permit the demons to speak, because they knew him. (Mk 1:32-34)

Later Mark says that a greater crowd, which includes people from different regions and provinces, gathered around Jesus, saying:

... a great crowd followed, from Galilee and Judea and Jerusalem and Idumea and from beyond the Jordan and from around Tyre and Sidon. When the great crowd heard all that he was doing, they came to him. And he told his disciples to have a boat ready for him because of the crowd, lest they crush him, for he had healed many, so that all who had diseases pressed around him to touch him. And whenever the unclean spirits saw him, they fell down before him and cried out, 'You are the Son of God'. (Mk 3:7-11)

Though not known by these names, infectious diseases such as tuberculosis, skin diseases, dysentery and eye disease spread fast in crowded places (Nutton 2012). How vulnerable was Jesus to communicable diseases while being surrounded by sick multitudes each day? Previous interpretation took three perspectives. Firstly, from a social discursive perspective, Morton Smith regarded the healing stories as aretalogies functioning to praise the healer. Their veracity is not as important as their social function as identity and fame trumpeters (Smith 1971). The second 
perspective, the dominant theological view, interprets the healing reports as a sign that Jesus is the messiah (Van der Loos 1965). The third perspective, from a social scientific perspective, is concerned with the social political environment in which the healing stories happened and views them as a sign of liberation and restoration (Malbon 1986; Van Eck 1993). For Malbon, an argument also echoed by Van Eck and Van Aarde, juxtaposed with the hegemonic and extractive empire and the temple, the healing stories of Jesus signify the restoration of the body and society done within Jesus' household (Van Aarde 2016; Van Eck 1993; 1995).

The perspective that I take is alluded to by Eusebius of Caesarea, who while citing the Hippocratic work On Breaths refers to Jesus as a vulnerable physician, saying:

[A] devoted physician, to save the lives of the sick, sees the horrible danger, yet touches the infected place and in treating another man's troubles brings suffering on himself: but we were not merely sick or afflicted with horrible ulcers and wounds already festering, but actually dying among the dead. (Ferngren 2009:64)

By touching the infected places and being in contact with the sick, Jesus the physician must have contracted some infectious diseases.

\section{Infectious diseases}

Three major problems beset this study. Firstly, the people during biblical times had no knowledge of viruses and bacteria; thus, they only had a broad conceptualisation of disease. Without modern knowledge, medical tests and instruments to help categorise terminal conditions such as cancer from minor conditions such as fever, all sickness was described as disease (Nutton 2012). Secondly, and related to the first point, only the observable symptoms were explained, meaning that other symptoms that were hidden from the eyes could not be detected. Lastly, and most importantly, people during the times of Jesus had no concept of infection as we have it today. Instead they understood disease as something 'that affects an individual and had its origin with the individual's own physical makeup as affected by his or her own lifestyle' (Nutton 2012). To be sick was the person's fault, either from a religious point of view of sinning against the gods or weakness in one's bodily fluids or balance, resulting in allowing sickness to enter.

However, infectious diseases, though known or described differently, were real. The increase in the population of various Greek cities by 10 CE provided a climate for infectious diseases such as diarrhoea, cough, smallpox, parasites, dysentery, tuberculosis and many others. For example, from an average population of 15 000, cities like Athens, Syracuse, Carthage, Corinth, Antioch, Ephesus and Rome increased to 750000 and 1 million people. Equally, villages like Capernaum increased to a population of 3000 (Nutton 2012). However, the population of Capernaum is debatable. Meyers and Strange give Capernaum the same population size as a city, 15000 (Meyers \& Strange 1981). Such a figure is unlikely.
On the other hand, Jonathan Reed gives Capernaum a measurement of 17 hectors and a maximum population of between 600 and 1700, much lower than that of Nutton. While the adoption of the Roman sewer system in many cities helped with drainage and removing stagnant water, it did not totally help regarding the general health of most cities. Though the rich lived in luxurious and spacious houses, accommodations in cities were crowded places. Cemeteries and stagnant waters provided a fertile ground for flies and parasites. One good site for contracting contagious diseases in cities was the public baths. While the public bath was regarded as a sign of civilisation, it led to cross-infection of fungal infections, skin diseases, tuberculosis and others. The same can be said of villages such as Nazareth and Capernaum (Reed 2002).

Some city epidemics were quite catastrophic. For example, as recorded by Tacitus, in 65 CE in Rome, an unknown epidemic killed 30000 people, affecting even senators and equestrian families, and was only ended by the cold winter weather (Scheidel 2003). Furthermore, in Greece, the plague of 430 BCE almost wiped out the entire population (Nutton 2012; Scheidel 2003). In 166-172 CE, a skin disease similar to smallpox, thought to have been brought by the Roman army from the east, spread from Rome, Egypt and Asia (Scheidel 2003). Most infectious diseases spread easily because of the crowded multistorey buildings occupied by the poor. In contrast, the rich would build their houses on the hillsides of cities away from the city population. To avert catastrophic plagues, city houses were supposed to have good ventilation or be built away from 'swamps and marshes, fumaroles and stinking corpses' (Nutton 2012; Scheidel 2003). Low-lying areas near swamps or slow moving waters were known for malaria, cough in winter, parasites, diarrhoea, dysentery and eye diseases.

\section{Ideas about health and preventive hygiene}

Because of fear of infectious diseases the Talmud, the life manual for all Jews, has 213 ceremonial rules concerning hygiene. Firstly, the surrounding areas were required to be clean. In Berakot of the Talmud, a person should not expose oneself to human or animal excretions (Ginzberg \& Halivni 1941). If one smells an odour, one should move away because the air is polluted. Bad air was associated with flies, which carry disease (Cohen 1921; Rosner 1977). The idea of clean air was a metaphor for everything that surrounds a person. If the air is unclean, it affects the body and its equilibrium. The same teaching is found in the Hippocratic tradition's On Airs, Waters and Places, which dealt with the environment and health (Nutton 2012). In addition, the Ketubot of the Talmud taught that clean air and sunlight heal disease (Rosner 1995). Because of fear of contaminated air, narrow streets were to be avoided. Equally, stagnant water was to be avoided. No Jew was to live in a city with public baths, as they were suspected of spreading diseases (Freedman \& Epstein 1948; Rosner 1977). 
Concerning the importance of clean air, Mark's Jesus violated all aspects regarding the need for clean air. Most of Jesus' healing was done inside houses (Malbon 1986; Van Eck 1993). Though a house conjures a metaphor of privacy and family, with regards to clean air it was a congested space, a breeding ground for infectious disease. In Mark 1:33, after healing Peter's mother-in-law, Mark's aretalogy says, 'the whole town gathered at the door and Jesus healed many who had various diseases'. From a theological perspective, it is a plausible statement that advances the argument of a helping and divine Jesus. However, from the perspective of infectious disease, Jesus and the crowd were vulnerably exposed to infectious diseases.

Secondly, the Talmud Shabbat taught personal cleanliness (Cohen 1935). Bodily discharge was a sign of being unhealthy. Thus, bodily fluids from the eyes, nose or any other part of the body were to be avoided. Thorough cleaning of hands was required for the patient before touching food. The Shabbat teaches that sickness is an imbalance within the body. To deal with the imbalance the body should shed unclean fluids, making all excretions unclean. After visiting the sick, people would ritually cleanse themselves and even change the clothes worn during the visit.

The story of the woman in Mark 5 with the flow of blood is the clearest example of Jesus coming into contact with human fluids. Clearly in an aretalogical style, the woman consulted many other physicians, who did not help. Fortunately, upon meeting Jesus her flow of blood stopped, but no further explanation is given by Mark regarding the ritual cleanliness of the crowd and the disciples who had been in contact with the sick people. This makes the reader wonder whether, in the process of following Jesus, the crowd was vulnerable to infectious disease.

Thirdly, physicians were more at risk and extra care needed to be taken. Besides having licences from city officials regarding their activities, physicians were suspect in the public's eyes. The Talmud's Baba Batra forbade an itinerant physician from being given accommodation for two reasons. Firstly, they attracted sick people, who might bring infectious diseases to the neighbourhood. Secondly, for peace, people would not sleep well from hearing moaning, sick patients from a nearby house (Epstein \& Simon 1935). The physician's house would be well marked with a haruta - the branch of a palm or peach tree - to alert passers-by concerning the ambivalent nature of the place as a place of recovery but also about the possible danger from infectious diseases (Rosner 1977).

Because travelling was slow and might take several days by foot or by caravan, visitors and caravans were suspected as carriers of diseases (Neusner 2007). Most people only knew their villages and the surrounding areas (Nutton 2012). Visitors and carriages from afar were supposed to be ritually cleansed before entering the village (Nutton 2012). The ambivalence with which itinerant healers and travellers are treated, in my view, provides a lens into re-describing the perception of Jesus by various villages.

\section{Reading Mark 1:40-45 as story about hygiene}

From a hygienic and ritual perspective in reading Mark 1:4045 concerning the healing of the leper, the meaning may emerge differently. In the story, Mark reports that, before entering the village, possibly of Capernaum, Jesus met a leper-a man with an infectious skin condition. A conversation ensued after the infected man requested healing from Jesus. Indeed, according to the oral Talmud's teaching regarding cleanliness, Jesus was supposed to move away. Instead, Jesus entertained the moment of being praised as a healer and 'reached out his hand and touched the man' (Mk 1:41). By doing so, Jesus, in the eyes of onlookers, contracted the skin disease. Mark's aretalogy wants the reader to be diverted from the horrible scene by saying 'immediately the leprosy left him and he was cleansed' (Mk 1:42). While listeners may have been moved by the horrible act, 'the aha moment', they were not convinced by the narrator's attempt to gloss over the event by saying that the infectious man was healed. Plausibly, what follows tells us that the touching of the skin of the infectious man was the point of conflict with the villagers in Capernaum. Before Jesus arrived at the village, the man had told all the villagers that he was ritually pronounced clean. Consequently, Mark reports saying, 'as a result, Jesus could no longer enter a town openly but stayed outside in lonely places. Yet people still came to him from everywhere' (Mk 1: 45b).

The story illustrates and confirms the ambivalent reception given to travellers and itinerant physicians like Jesus of Nazareth. On the positive side, physicians from afar were revered for having better medicine that could heal any kind of sickness. Referring to Jesus, Arnobius of Sicca describes Jesus as a healer from afar. Located in Carthage (255-330 $\mathrm{BCE})$, Arnobius gives an apology for people who did not want to convert to Christianity:

[I] $\mathrm{f}$ a physician had come to you from far-away countries and from regions never known to you, promising medicine which would ward off from your bodies absolutely all kinds of diseases and complaints, would you not all have run to him vying with one another to reach him first. Would you not have received him in your family walls with every kind of attention and shower him with honors? Would you not want that kind of medicine to be reliable and genuine, which guaranteed that you would be free from innumerable bodily ills even to the end of your lives? Even if the matter were doubtful you would yet put yourselves in his care and you would not hesitate to drink down the unknown dose, induced to do so by the prospect set before you of gaining health and by a love of security. Like a bright light Christ appeared to us as the herald of very great news, bringing also an omen of prosperity and a message of good health to those who believe. (Arnobius of \& McCracken 1949:112)

From the citation, Arnobius paints Jesus as a healer from afar whose exotic healing herbs are the desire of all. However, the other perspective is the picture presented in the Talmud: that 
itinerant healers were themselves carriers of infectious diseases, suspected of bringing sickness into villages or cities. From this perspective and in view of the story of the leper, Eusebius' description of Jesus as vulnerable healer fits the concerns of the villagers of Capernaum. For Eusebius, Jesus was a devoted physician who saved the lives of the sick, saw the horrible danger, yet touched the infected place and in treating another man's troubles brought suffering on himself.

Furthermore, Mark 3:7-12, from the perspective of infectious disease, implies a genuine fear from Jesus of infectious disease. This time Jesus withdrew to the lake, where a large crowd followed him 'from Judea, Jerusalem, Idumea and the regions across the Jordan and around Tyre and Sidon' (Mk 3:8). Despite Mark's aretalogy in expressing Jesus as the best healer, when the crowd started gathering around Jesus, Mark expressed genuine fear of infection. He says, 'because of the crowd he told his disciples to have a small boat ready for him to keep the people from crowding him' (Mk 3:9). Contrary to the theological perspective, which regards the multitude of people as a sign of Jesus' messiahship, Jesus' withdrawal into the boat and away from the people was a sign of fear of infectious disease (Keck 1965). Interpreted from the perspective of the Talmud concerning the need for clean air, Jesus expressed genuine fear. The sick people who came to him would spread the sickness to him - a genuine fear of all physicians during that time. In this case, the boat was a device to distance Jesus from the people. In addition, being out surrounded by the cleansing water provided good air circulation around him.

\section{Conclusion}

This study looks back into health and hygiene conditions within Jewish and Greco-Roman cities and villages. Firstly, the Jewish ritual laws were designed to avoid infection and even death from tuberculosis, diarrhoea, dysentery and many other infectious diseases. While cities had advanced through facilities such as Roman sewers, many infectious diseases bred in various places such as cemeteries, swamps and crowded city places. The outbreak of an infectious disease was catastrophic. Furthermore the Jewish Talmud gives insight into various strategies for preventing infectious diseases by avoiding crowded places, excretion and odours. Strict ritual cleanliness was required through washing of hands and even quarantining the sick. For safety, cities required a physician and no Jew would stay in a city without a physician and public baths. Jesus, as an itinerant healer, seemed to operate outside the periphery of cities and villages. The illustrative example of Jesus healing the leper in Capernaum reveals evidence of fear of infectious disease by the villagers. Having touched and interacted with the infectious man, the villagers' fear is palpable. They could not allow Jesus to enter the city. The Capernaum episode illustrates the ambivalent reception given to physicians - they were envied for their exotic herbs yet feared for bringing diseases into cities and villages. This fear was protected by the legal requirement to have all physicians known concerning their modus operandi and the vigilance of the neighbours, who would not allow itinerant healers like Jesus to be given accommodation, fearing the coming of sick people. Yet Mark $3: 7-12$, the earliest tradition of Jesus dealing with a crowd, shows that Jesus was not clueless regarding infectious diseases; he actually stepped away in a boat, fearing infection by disease.

\section{Acknowledgements Competing interests}

The author declares that he has no financial or personal relationships which may have inappropriately influenced him in writing this article.

\section{References}

Arnobius of S. \& MCCracken, G.E., 1949, The case against the pagans, Methuen, London.

Cohen, A., 1921, The Babylonian Talmūd: Tractate Berākōt: Translated into English for the first time, with introduction, commentary, glossary and indices, Cambridge University Press, Cambridge, England.

Cohen, B., 1935, Shabbat, Posy-Shoulson Press, New York.

Epstein, I. \& Simon, M., 1935, Baba bathra, Soncino Press, London.

Ferngren, G.B., 2009, Medicine \& health care in early Christianity, Johns Hopkins University Press, Baltimore, MD.

Fiorenza, E.S., 1979, "YYou are not to be called father": Early Christian history in a Feminist perspective', CrossCurrents 29, 301-323.

Freedman, H. \& Epstein, I., 1948, Zebahim, Soncino Press, London.

Ginzberg, L. \& Halivni, D., 1941, A commentary on the Palestinian Talmud: Berakot 1 and 2, Jewish Theological Seminary Press, New York.

Horsley, R.A., 2001, Hearing the whole story: The politics of plot in Mark's gospel, Westminster John Knox Press, Louisville, KY.

Keck, L.E., 1965, 'Mark 3: 7-12 and Mark's Christology', Journal of Biblical Literature 84, 341-358.

Malbon, E.S., 1986, Narrative space and mythic meaning in Mark, HarperCollins Publishers, New York.

Meyers, E.M. \& Strange, J.F., 1981, Archaeology, the rabbis, \& early Christianity, Abingdon Press, Nashville.

Moxnes, H., 2003, Putting Jesus in his place: A radical vision of household and kingdom, Westminster John Knox Press, Louisville.

Myers, C., 1988, Binding the strong man: A political reading of Mark's story of Jesus, Orbis Books, Marknoll, NY.

Neusner, J., 2007, A history of the Mishnaic Law of appointed times, part 4: Besah, Rosh Hashanah, Taanit, Megillah, Moed Qatan, Hagigah: Translation and Explanation, Wipf and Stock Publishers, Eugene, OR.

Nutton, V., 2012, Ancient medicine, Routledge, New York.

Reed, J.L., 2002, Archaeology and the Galilean Jesus: A re-examination of the evidence, A\&C Black, Harrisburg, PA.

Rosner, F., 1977, Medicine in the Bible and the Talmud: Selections from classical Jewish sources, Ktav Pub. House, New York.

Rosner, F., 1995, Medicine in the Bible and the Talmud: Selections from classical Jewish sources, KTAV Publishing House, Inc., New York.

Scheidel, W., 2003, 'Germs for Rome', in C. Edward \& C. Woolf (eds.), Rome the cosmopolis, pp. 158-176, Cambridge University Press, Cambridge.

Smith, M., 1971, 'Prolegomena to a discussion of aretalogies, divine men, the gospels and Jesus', Journal of Biblical Literature 90, 174-199.

Van Aarde, A., 2016, 'Understanding Jesus "healings"', Scriptura 74, 223-236.

Van Der Loos, H., 1965, The miracles of Jesus, Brill Archive, Leiden.

Van Eck, A., 1993, 'Sickness and healing in Mark: A social scientific interpretation', Neotestamentica 27, 27-54.

Van Eck, E., 1995, Galilee and Jerusalem in Mark's story of Jesus: A narratological and social scientific reading, HTS, Pretoria. 